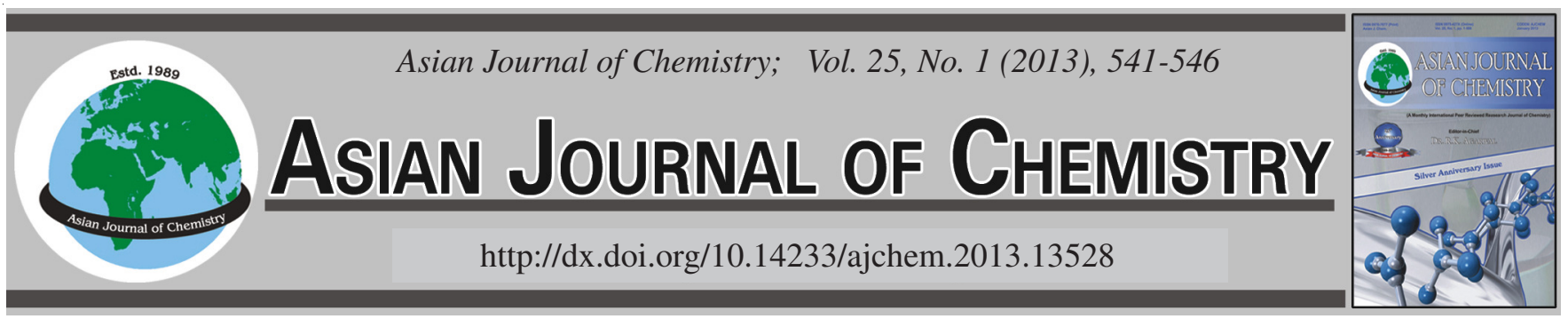

\title{
Study on Potassium Bearing Minerals in Sand Fraction Through X-Ray Diffraction Techniques
}

\author{
R.S. Kaliramana*, B.S. Pannu and J.P. Singh
}

Department of Soil Science, Chaudhary Charan Singh Haryana Agricultural University, Hisar-125 004, India

*Corresponding author: E-mail: raghubir29@ rediff.com

(Received: 30 January 2012;

Accepted: 6 August 2012)

AJC-11921

The potassic feldspar, mica were the prime sources of potassium bearing minerals indentified in these soils. The feldspar and mica were concentrated mainly occurred in the coarse fraction of the soils. The soil of aeolian plain and rugged hilly terrain of Aravalli range of semiarid region contained high amount of feldspar than mica, but the reverse trend was observed in rest of the soils of this region. The difference in the mineralogical composition within the soils of semi-arid region was found to be originated from the source of alluvium and parent rocks.

Key Words: Haryana soils, Potassic feldspar and mica, Mineralogical composition.

\section{INTRODUCTION}

It has been observed that the parent material of the alluvial soils of India are almost of similar types, derived from the Himalayan rocks by various rivers of Indo-Gangetic and Brahmaputra system during Pleistocene to recent time ${ }^{1}$, but the soils still differ considerably in the mineralogical composition and other important soil characters, which can be seen as a direct effect of the climatic differences. Potassium is the limiting fertilizer element next to nitrogen and phosphorus in Indian soils. Research work on potassium dynamics is lacking behind because of the general impression that most of the Indian soils are well supplied with this element intensification of agriculture had led to higher removal of $\mathrm{K}$ from soils, which has necessitated in the progressively increasing usage of potassium fertilizer. The most important potash bearing silicate mineral present in the alluvial soils of India were feldspars and mica. The identified species of potassic feldspars were microcline and orthoclase. Muscovite, biotite and illite were the major species of mica present in the soil, except illite. All other species of silicate minerals were mainly concentrated in the coarser fractions of soil. In the soils of arid regions of southern Haryana, Punjab and Eastern Rajasthan, feldspars are either in equal proportion or second most abundant mineral after quartz $\mathrm{z}^{2-4}$.

\section{EXPERIMENTAL}

X-ray diffraction analysis of silt: The aggregate samples of silt particles were subjected to X-ray diffraction analysis without ion saturation. The setting of the instrument was changed to $35 \mathrm{KV}, 25 \mathrm{~mA}$ and $400 \mathrm{CPS}$ to record the hkl (060) reflection 3 to 65 degree $2 \theta$ for identification of mica type minerals.

X-ray diffraction analysis of sand: The powdered sample of sand fraction was prepared in Phillips power sample holders using glass slide on the lower side of the holder to make a cavity. The sample surface was smoothened by pressing glass silde and analyzed through the X-ray diffraectometer. The diffractograms of the samples were recorded from $3^{\circ} 2 \theta$ to $65^{\circ} 2 \theta$.

Interpretation of X-ray difftractograms: X-ray diffractograms recorded the diffraction maxima which are produced due to diffraction of X-rays from a succession of regularly spaced atoms. The inter atomic distances in a crystal usually produce an array of diffraction maxima which is used to identify the mineral. The X-ray diffrctograms, thus obtained, were critically examined for their possible mineralogical composition. The peaks obtained in these diffractgrams were marked and their corresponding $2 \theta$ angles were located. The d-values for all the angles were calculated from the $2 \theta$ values using Bragg's law, expressed as: where,

$$
\begin{aligned}
& \mathrm{n} \lambda+2 \mathrm{~d} \operatorname{Sin} \theta, \lambda=\text { Wavelength of } \mathrm{X} \text {-rays }(1.5418 \AA) \\
& \theta=\text { angle of diffraction, } \mathrm{n}=\text { order of diffraction } \\
& \mathrm{d}=\text { inter planner or lattice spacing }
\end{aligned}
$$

After calculating the d-values, from all the treatment of clay samples and also from sand silt fraction, the results were complied to analyze the composition of different minerals using the ASTM (American Society for Testing Material) data cards as standards. 
Semi quantitative estimation of minerals: Semi quantitative estimation of minerals were calculated by measuring the areas of first order basal reflection peaks after appropriately setting the background lines according to the procedure ${ }^{5}$ with some modification as suggested by Ghosh and Dutta ${ }^{6}$. This procedure involves the measurement of area of Ist order basal reflection peaks for different clay minerals after appropriately setting of the background line. The peak's area are further corrected for the instrument geometry effects and polarization factor and then compared with each other for relative percentage of each component in the samples in different site of Haryana (Fig. 1).

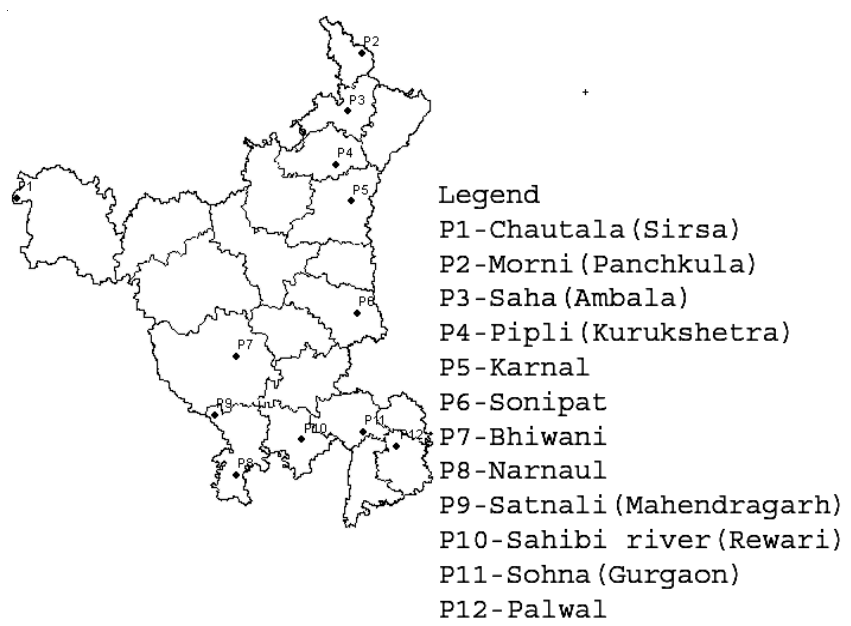

Fig. 1. Map showing the sampling sites in Haryana

\section{RESULTS AND DISCUSSION}

The sand fraction of the soils (Table-1) collected from the aeolian plain Chautala, (Sirsa) and Bhiwani the dominance of quartz (50 to $53 \%$ ) followed by feldspars and mica. Soils showed very high amount of feldspars (26 to $32 \%$ ) as compared to mica (17 to $23 \%$ ) (Table-1). In the silt fraction slightly higher content of mica was observed in Chautala (Sirsa) soil. In addition to these minerals small amounts of chlorite (2 to 6 $\%$ ), kaolinite (3 to $6 \%$ ) was also observed diffractrograms of the silt fraction (Figs. 2 and 3) showed the same trend i.e. dominance of quartz followed by feldspars and mica. In addition to these mineral small amount of chlorite (2-6\%), kaolinite (3-6\%) and interstratified minerals were also found by Shanwal and Dutta ${ }^{7}$ who reported the dominance of feldspar in silt fraction of sandy soils. The composition of minerals particularly mica and feldspar in sand and silt fraction of Saha (Ambala) soil under alluvial plain of upper terrace had no difference with the soils of alluvial plain. But Siwalik range Morni (Panchkula) showed some variation marked by an increase in the amount of quartz in the sand fraction (57 to $69 \%$ ) as well as silt fraction (44 to $48 \%$ ). Feldspars content of sand decreased appreciably (9 to $12 \%$ ). The typical X-ray diffractograms of sand and silt fraction of Sahibi river basin are shown in Fig. 4. The X-ray diffractograms of sand fraction are dominated by diffraction peaks of quartz $(4.23,3.32,2.46$, $2.28,2.13,1.98,1.82,1.67$ and $1.54 \AA$ ), second dominated mineral is mica marked by their peaks at 3.197, 3.248 and $2.949 \AA$. The amount presence of alkali feldspar is also marked

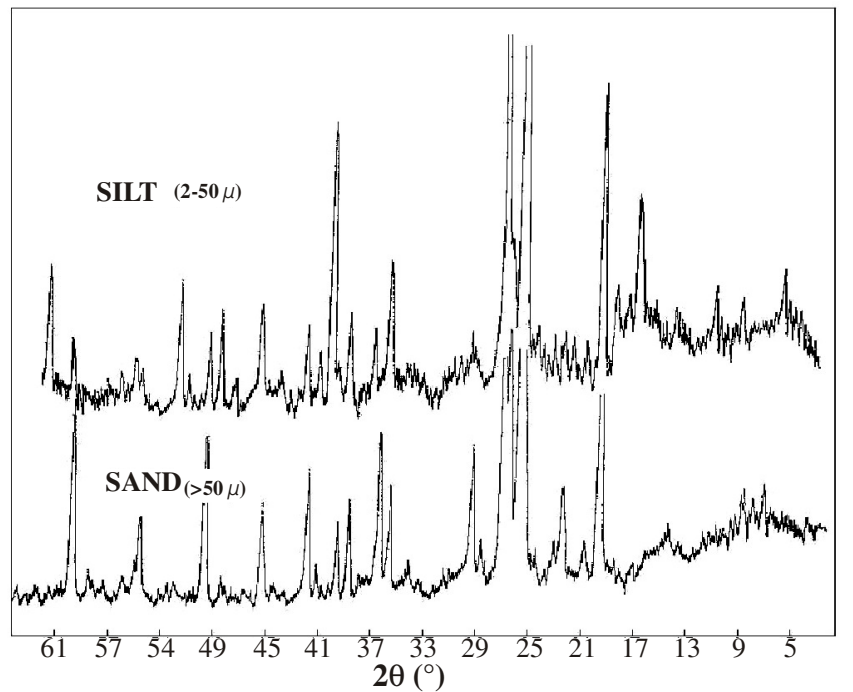

Fig. 2. X-ray difractograms of sand and silt fraction of Chautala soil (0-25 $\mathrm{cm})$

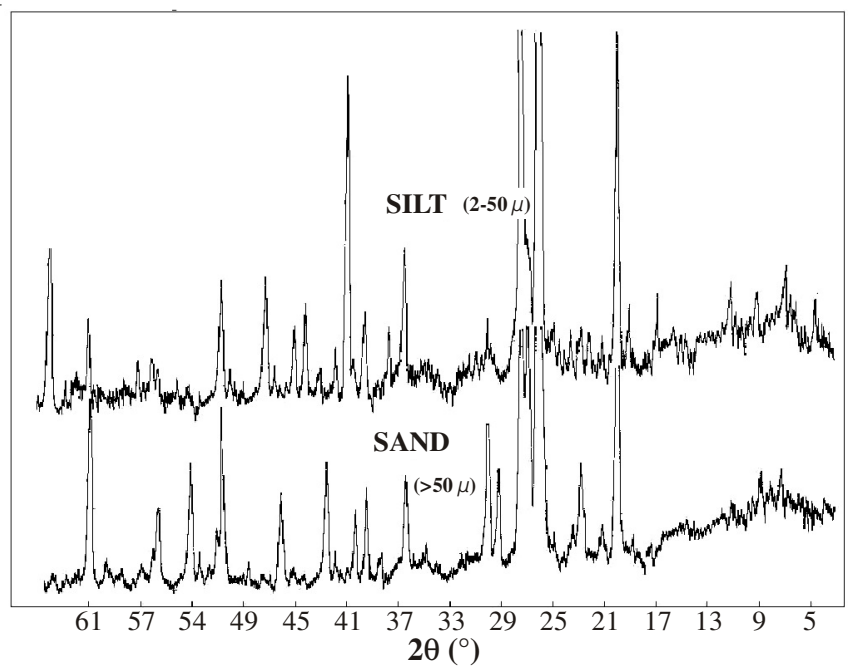

Fig. 3. X-ray difractograms of sand and silt fraction of Bhiwani soil (0-25 $\mathrm{cm})$

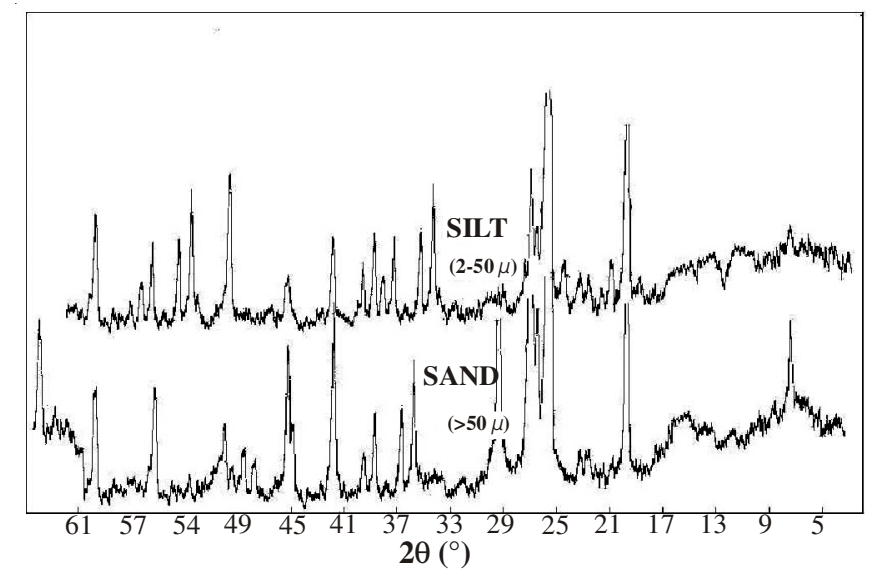

Fig. 4. X-ray difractograms of sand and silt fraction of Sahibi soil (0-25 $\mathrm{cm})$

by the diffraction maximum at 3.18, 3.24, 3.17 and $4.02 \AA$. The X-ray diffractograms of silt fraction showed the dominance of quartz marked by sharp and strong refraction at 4.26 and 


\begin{tabular}{|c|c|c|c|c|c|c|c|c|c|c|}
\hline \multicolumn{11}{|c|}{$\begin{array}{l}\text { TABLE-1 } \\
\text { SEMI-QUANTITATIVE ESTIMATION OF THE MINERALOGICAL COMPOSITION OF DIFFERENT PARTICLE SIZE FRACTIONS }\end{array}$} \\
\hline \multirow{2}{*}{ Depth $(\mathrm{cm})$} & \multicolumn{4}{|c|}{ Sand mineral $(\%)$} & \multicolumn{6}{|c|}{ Silt mineral (\%) } \\
\hline & $\mathrm{Q}$ & $\mathrm{F}$ & $\mathrm{M}$ & $\mathrm{Ch}$ & $\mathrm{Q}$ & $\mathrm{F}$ & $\mathrm{M}$ & $\mathrm{Ch}$ & $\mathrm{K}$ & ISM \\
\hline \multicolumn{11}{|c|}{ Profile-1 Chautala (Sirsa) soil } \\
\hline $0-25$ & 52 & 26 & 20 & 2 & 38 & 27 & 23 & 5 & 3 & 4 \\
\hline $26-50$ & 44 & 32 & 23 & 1 & 33 & 25 & 31 & 4 & 4 & 3 \\
\hline $51-75$ & 48 & 31 & 19 & 2 & 29 & 27 & 31 & 5 & 4 & 4 \\
\hline $76-100$ & 53 & 29 & 17 & 1 & 40 & 24 & 28 & 2 & 3 & 3 \\
\hline \multicolumn{11}{|c|}{ Profile-2 Morni (Panchkula) soil } \\
\hline $0-25$ & 57 & 18 & 23 & 2 & 48 & 20 & 22 & 4 & 4 & 2 \\
\hline $26-50$ & 61 & 15 & 21 & 3 & 45 & 18 & 28 & 3 & 4 & 2 \\
\hline $51-75$ & 66 & 14 & 18 & 2 & 46 & 15 & 24 & 6 & 5 & 4 \\
\hline $76-100$ & 69 & 12 & 17 & 2 & 44 & 18 & 23 & 6 & 5 & 4 \\
\hline \multicolumn{11}{|c|}{ Profile-3 Saha (Ambala) soil } \\
\hline $0-25$ & 54 & 19 & 25 & 2 & 41 & 22 & 26 & 6 & 5 & - \\
\hline $26-50$ & 50 & 23 & 25 & 2 & 38 & 19 & 32 & 5 & 4 & 2 \\
\hline $51-75$ & 52 & 19 & 24 & 5 & 39 & 21 & 31 & 4 & 3 & 2 \\
\hline $76-100$ & 46 & 24 & 28 & 2 & 45 & 18 & 28 & 5 & 2 & 2 \\
\hline \multicolumn{11}{|c|}{ Profile-4 Pipli (Kurukeshtra) soil } \\
\hline $0-25$ & 52 & 18 & 28 & 2 & 38 & 20 & 31 & 4 & 5 & 2 \\
\hline $26-50$ & 49 & 20 & 26 & 5 & 39 & 18 & 32 & 5 & 4 & 2 \\
\hline $51-75$ & 62 & 15 & 20 & 3 & 42 & 15 & 33 & 4 & 4 & 2 \\
\hline $76-100$ & 66 & 13 & 18 & 3 & 52 & 14 & 29 & 2 & 2 & 1 \\
\hline \multicolumn{11}{|c|}{ Profile-5 Karnal soil } \\
\hline $0-25$ & 45 & 21 & 29 & 5 & 37 & 20 & 32 & 4 & 5 & 2 \\
\hline $26-50$ & 50 & 23 & 24 & 3 & 37 & 18 & 35 & 3 & 6 & 1 \\
\hline $51-75$ & 54 & 21 & 20 & 5 & 39 & 22 & 29 & 4 & 4 & 2 \\
\hline $76-100$ & 56 & 18 & 23 & 3 & 33 & 23 & 37 & 2 & 4 & 1 \\
\hline \multicolumn{11}{|c|}{ Profile-6 Sonipat soil } \\
\hline $0-25$ & 38 & 28 & 32 & 2 & 38 & 16 & 33 & 5 & 8 & - \\
\hline $26-50$ & 45 & 26 & 26 & 3 & 36 & 18 & 36 & 4 & 6 & - \\
\hline $51-75$ & 44 & 24 & 29 & 3 & 30 & 21 & 42 & 3 & 4 & - \\
\hline $76-100$ & 46 & 22 & 31 & 1 & 28 & 24 & 41 & 3 & 4 & - \\
\hline \multicolumn{11}{|c|}{ Profile-7 Bhiwani } \\
\hline $0-25$ & 54 & 27 & 18 & 1 & 34 & 24 & 27 & 6 & 6 & 3 \\
\hline $26-50$ & 49 & 28 & 22 & 1 & 36 & 26 & 25 & 6 & 5 & 2 \\
\hline $51-75$ & 50 & 26 & 23 & 1 & 44 & 23 & 23 & 4 & 5 & 1 \\
\hline 76-100 & 53 & 26 & 20 & 1 & 41 & 24 & 28 & 3 & 4 & 1 \\
\hline \multicolumn{11}{|c|}{ Profile-8 Narnaul } \\
\hline $0-25$ & 59 & 25 & 16 & - & 46 & 18 & 24 & 6 & 6 & - \\
\hline $26-50$ & 63 & 23 & 14 & - & 42 & 24 & 22 & 8 & 5 & - \\
\hline $51-75$ & 68 & 20 & 12 & - & 51 & 21 & 20 & 4 & 4 & - \\
\hline 76-100 & 70 & 18 & 10 & 2 & 46 & 20 & 26 & 4 & 4 & - \\
\hline & & & & $-9 \mathrm{~S}$ & Tahe & ) soi & & & & \\
\hline $0-25$ & 61 & 22 & 16 & 1 & 45 & 19 & 21 & 6 & 7 & 2 \\
\hline $26-50$ & 64 & 24 & 12 & - & 40 & 22 & 23 & 6 & 5 & 4 \\
\hline $51-75$ & 63 & 26 & 11 & - & 42 & 24 & 24 & 4 & 4 & 2 \\
\hline 76-100 & 71 & 18 & 11 & - & 47 & 21 & 26 & 2 & 2 & 2 \\
\hline & & & & $\mathrm{e}-10$ & iver & soil & & & & \\
\hline $0-25$ & 53 & 24 & 19 & 4 & 32 & 22 & 32 & 6 & 8 & - \\
\hline $26-50$ & 49 & 26 & 21 & 4 & 31 & 24 & 34 & 5 & 6 & - \\
\hline $51-75$ & 58 & 21 & 17 & 4 & 35 & 22 & 33 & 4 & 6 & - \\
\hline 76-100 & 60 & 18 & 16 & 6 & 39 & 26 & 27 & 3 & 5 & - \\
\hline & & & & file-1 & $(\mathrm{Gu}$ & & & & & \\
\hline $0-25$ & 58 & 26 & 14 & 2 & 36 & 18 & 39 & 3 & 4 & - \\
\hline $26-50$ & 62 & 24 & 12 & 2 & 34 & 22 & 38 & 3 & 3 & - \\
\hline $51-75$ & 66 & 20 & 13 & 1 & 28 & 26 & 40 & 3 & 3 & - \\
\hline 76-100 & 74 & 15 & 10 & 1 & 30 & 23 & 41 & 3 & 3 & - \\
\hline & & & & $\operatorname{Prc}$ & alw: & & & & & \\
\hline $0-25$ & 44 & 20 & 32 & 4 & 34 & 20 & 38 & 3 & 3 & - \\
\hline $26-50$ & 40 & 28 & 28 & 4 & 26 & 22 & 42 & 3 & 4 & - \\
\hline $51-75$ & 48 & 21 & 26 & 5 & 31 & 24 & 38 & 5 & 4 & - \\
\hline $76-100$ & 52 & 19 & 24 & 5 & 35 & 26 & 34 & 6 & 3 & - \\
\hline
\end{tabular}


$3.33 \AA$ with its submultiples. Mica is the second dominated mineral, although not evident from the diffractogram, due to randomization of particles. Small amount of illite, kaolinite and chlorite were also observed. All forms of potassium were substantially higher in this region than the adjoining northern plains, reflecting the role of soil minerals particularly dioctahedral mica and potash feldspars originating the weathering of rocks of the Aravali hills and Aeolian deposits. The mineralogical make up showed higher proportion of trioctahedral mica than dioctahedral species in the soils of the arid region than the adjoining semi-arid region ${ }^{8,9}$.

The coarse fraction mineralogy of the alluvial plain of Haryana was quite different from the aeolian plain and hilly terrain of Aravalli range. Although the sand fraction of Palwal, Sonipat, Karnal and Pipli (Kurukeshtra) soils were dominated by quartz but it also contained high amount of mica (18 to $32 \%$ ) and feldspar (13 to $28 \%$ ). The content of quartz and mica in the silt fraction of these soils was nearly equal and varied between 26 to $52 \%$ and 29 to $48 \%$ respectively, the percentages of feldspars ( 15 to $26 \%$ ) was closely related to its content in the sand fraction. Silt fraction also contained chlorite ( 3 to $10 \%$ ) and kaolinite ( 2 to $8 \%$ ) besides the primary minerals. The coarse fraction mineralogy of the alluvial plain of Haryana was quite different from the Aeolian plain and hilly terrain of Aravalli range. Mica consists of both the species i.e. muscovite as well as biotite. The representative X-Ray diffractograms of Figs. 5-8 showed similar kind of peaks confirming the uniform mineralogical composition of sand fraction. A small amount of chlorite ( 2 to $5 \%$ ) was also detected by the specific peak at 14.25 and $7.02 \AA$. The diffraction maxima at 3.18, 3.24, 3.17 and 4.02 A marked the presence of alkali feldspars. The mineralogy of silt fraction is more or less similar to that sand fraction except the high quantity of mica. This pattern of mineral distribution in the coarse fraction of alluvial soils also reported ${ }^{3,10}$. The silt fraction is closely similar in the minerals set up between old alluvial plain and recent flood plain of Yamuna. Quartz is dominated mineral followed by mica, feldspar and chlorite.

The mineralogy composition of Narnaul, Satnali (Mahendergarh) and Sohna (Gurgoan) soils was based on semi

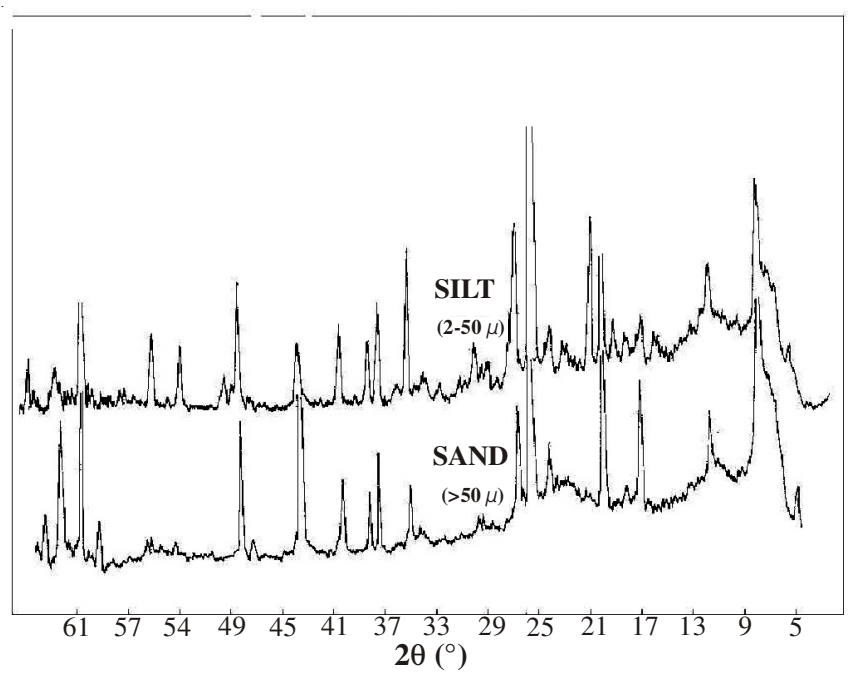

Fig. 5. X-ray difractograms of sand and silt fraction of Pipli soil $(0-25 \mathrm{~cm})$

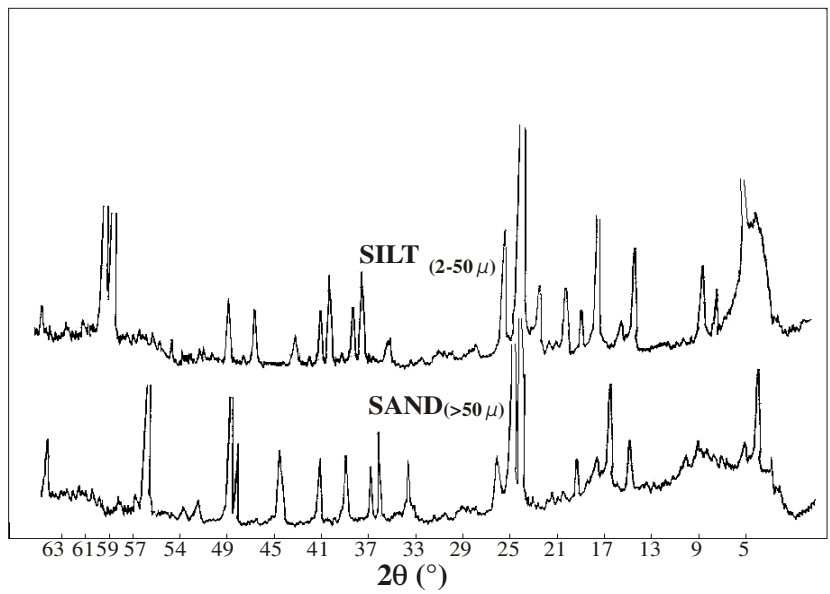

Fig. 6. X-ray difractograms of sand and silt fraction of Karnal soil (0-25 $\mathrm{cm})$

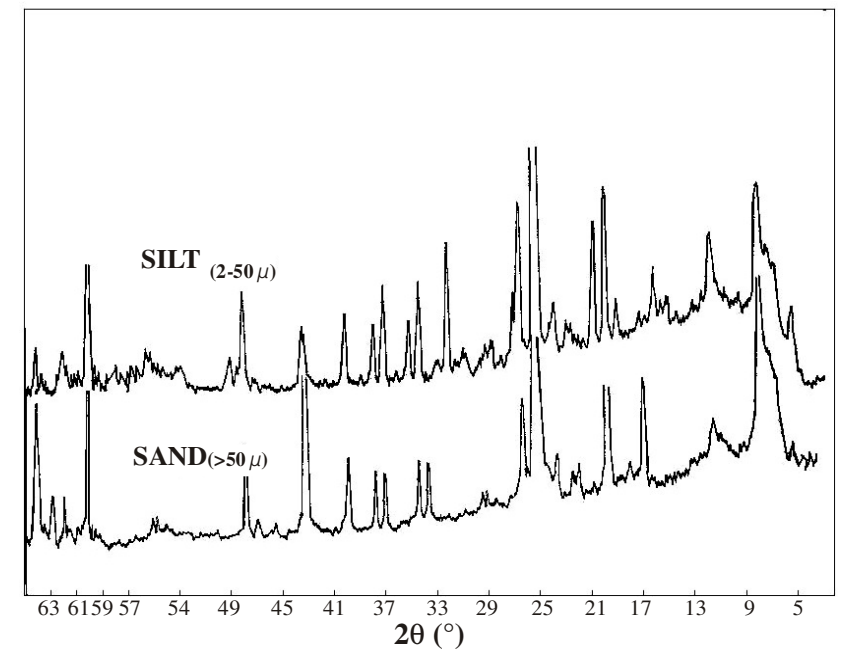

Fig. 7. X-ray difractograms of sand and silt fraction of Sonipat soil (0-25 $\mathrm{cm})$

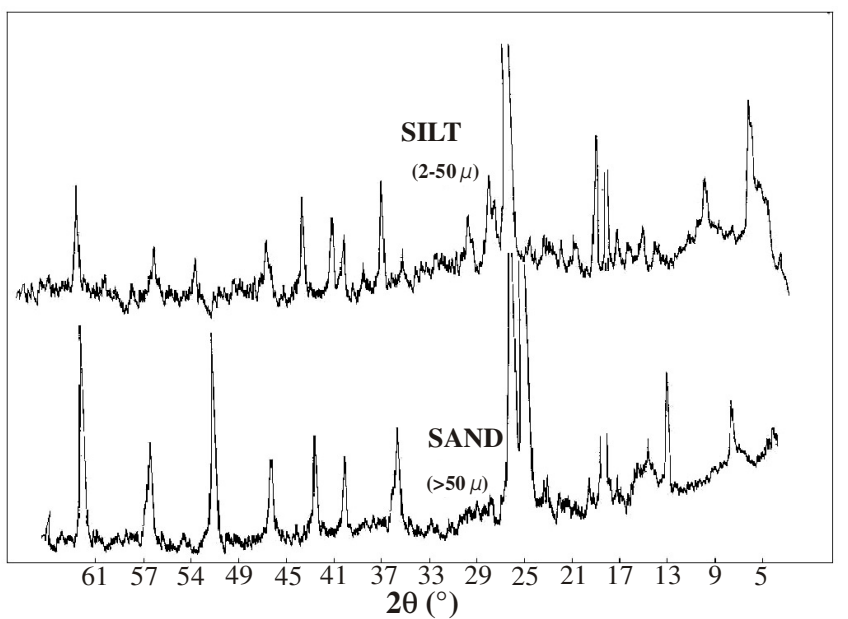

Fig. 8. X-ray difractograms of sand and silt fraction of Palwal soil (0-25 $\mathrm{cm})$

quantitative estimation showed that quartz is dominant mineral (58 to $74 \%$ ) followed by feldspar (15 to $26 \%$ ), mica (10 to $16 \%$ ), vermiculite (4 to $9 \%$ ), smectite (1 to $6 \%$ ), chlorite (1 to $6 \%$ ) and interstratified minerals ( 2 to $4 \%$ ) The 
sand and silt fraction of Narnaul, Satnali showed similar composition to that of Sohna except high amount of feldspar and mica. The mineralogy composition of Sahibi river basin (Rewari) soil was based on semi quantitative estimation are shown in Table-1 that quartz is dominant mineral (53 to $60 \%$ ) followed by feldspar (18 to $24 \%$ ), mica (16 to $21 \%$ ), vermiculite ( 2 to $12 \%$ ), smectite (9 to $19 \%$ ), interstratified minerals ( 2 to $4 \%$ ) and other ( 2 to $5 \%$ ). The sand and silt fraction of Sahibi river basin was similar composition. The representative $\mathrm{X}$-ray diffractgrams of sand and silt fraction depicted in (Figs. 9-11). The random oriented diffractograms of sand fraction of Satnali, Narnaul and Sohna soils under rugged hilly terrain Aravalli range that it is mainly composed of quartz which register its peaks at $4.26 \AA$ and its multiples. Small amount of mica is also observed (10, 5 and $3.33 \AA$ peaks). Medium and sharp reflection at $3.575,3.465$ and $3.17 \AA$ belong to plagioclase feldspar group. Small amount of chlorite is also detected by the presence of peaks at 14.25 and also $7.02 \AA$. Interstratified mineral which can be seen as low intensity weathering product of primary mineral and quartz grain are angular and sharp edged showing their origin to the rocks. The feldspar surface is pitted and somewhat corrugated shows sign of alteration. The heavy sand minerals grains are also angular and acute ${ }^{7}$. The silt fraction is mainly composed of mica followed by fairly

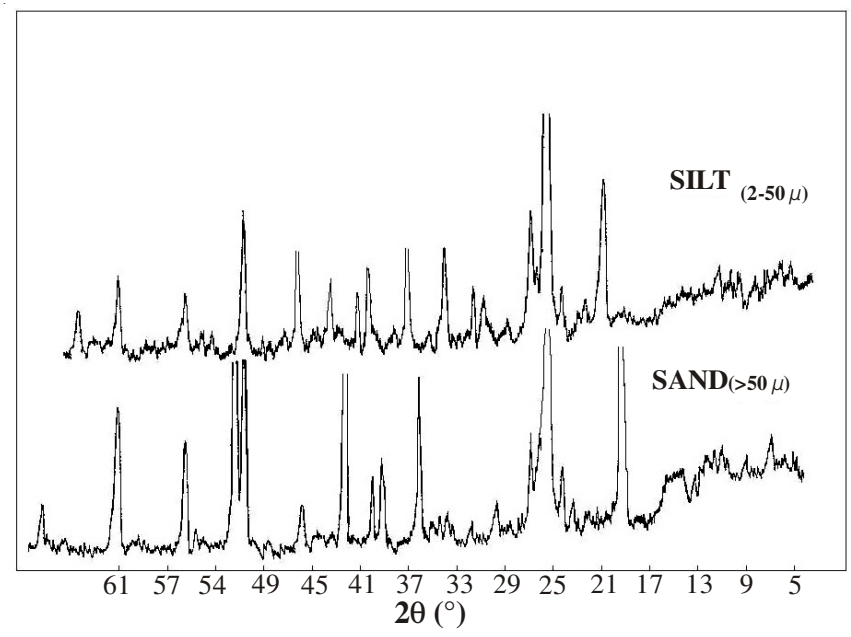

Fig. 9. X-ray difractograms of sand and silt fraction of Narnaul soil (0-25 $\mathrm{cm})$

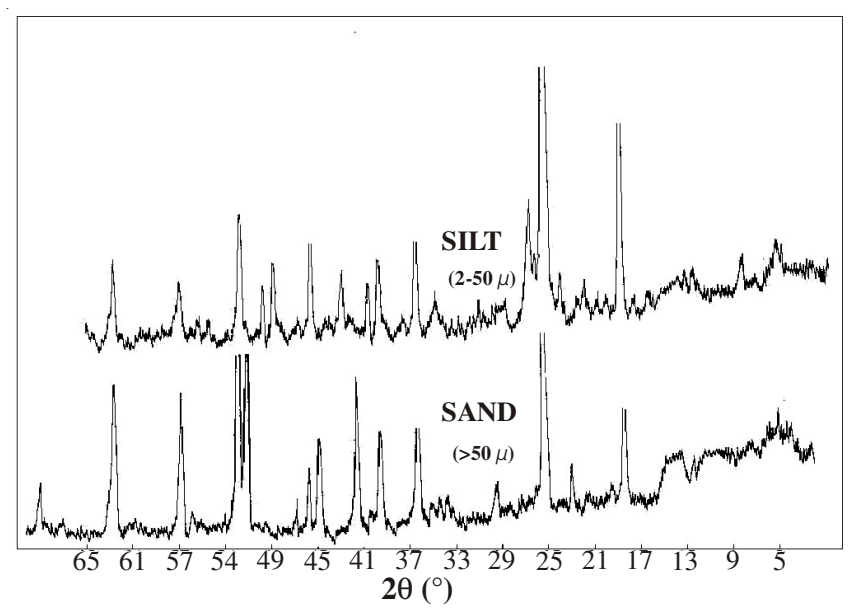

Fig. 10. X-ray difractograms of sand and silt fraction of Satnali soil (0-25 $\mathrm{cm})$

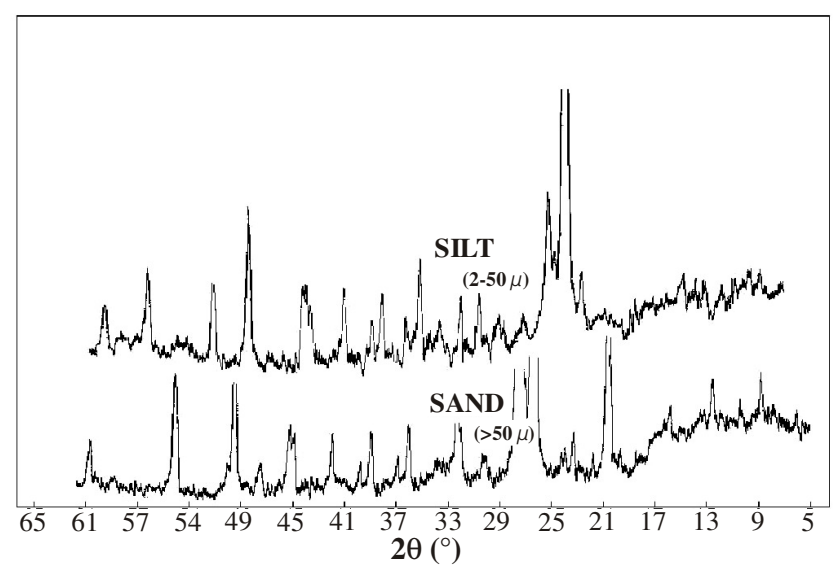

Fig. 11. X-ray difractograms of sand and silt fraction of Sohna soil (0-25 $\mathrm{cm})$

good amount of quartz, feldspars and chlorite. Other associated minerals in terraces are kaolinite and interstratified mineral. The sand and silt fraction of Narnaul and Satnali soils showed similar composition to that of Sohna soil except high amount of feldspar and mica. High amount of feldspar may be attributed to Aeolian activity and mica to the alluvium brought down by seasonal rivers. This indicates their origin from sedimentary rocks.

The sand fraction of the Aeolian plain (Chautala and Bhiwani) showed very high amount of feldspars (26 to32\%) as compared to mica ( 17 to $23 \%$ ) reflected by sharp and strong diffraction maxima of feldspars at 3.24 and $3.17 \AA$ to weak peaks at 10 and $3.33 \AA$ for mica in the representative X-ray diffractograms of both region (Figs. 2 and 3). It showed the dominace of plagioclase feldspars in this area followed by microcline and albite. Small amount of illite was also observed with its diffraction peaks at 14 and $7 \AA$. The low content of mica in both soils are related to parent rocks chiefly sand stone, rhyolite, granite which are less in mica content. The sand fraction hardly shows flakes of mica. This clearly indicates its origin to country rocks of Rajasthan which are deficient in mica. The quartz and feldspars grains did not show any

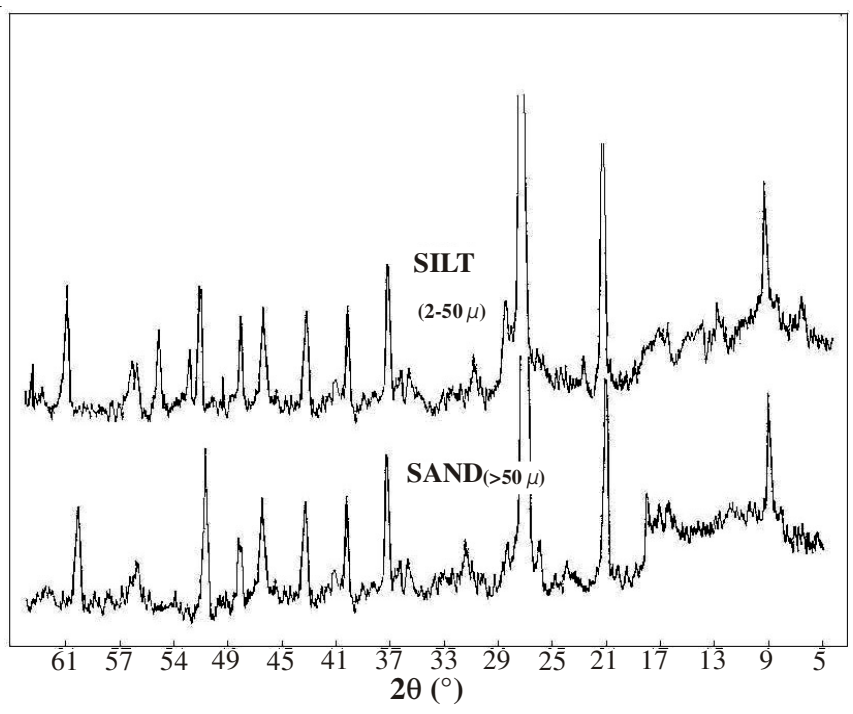

Fig. 12. X-ray difractograms of sand and silt fraction of Morni soil (0-25 $\mathrm{cm})$ 
particular feature associated with chemical weathering although crowded surface and cross pattern on few plagioclase were observed under microscope. This type of features have also been reported in Aeolian soils of Rajasthan ${ }^{2}$. The results are in accordance with findings the earlier study ${ }^{4,7}$.

\section{Conclusion}

Potassium bearing minerals were studied in different particles size fraction through X-ray diffraction and transmission electronic microscope (TEM). The potassic feldspar, mica and illite were the prime potassium bearing minerals indentified in these soils. The feldspar and mica were concentrated mainly in the coarse fraction of the soils. The coarse fraction of the soils of aeolian plain and rugged hilly terrain of Aravalli range of semi-arid region (Chautala, Bhiwani, Narnaul and Sohna soils) contained higher amount of feldspar, mica, but the reverse trend was observed in the rest of the soils of this region. Both alkali and plagioclase feldspar were indentified in these soils. The amount of latter species of feldspar was found higher in aeolian and Aravalli range. Mica in these soils was trioctahedral as well as dioctahedral in varying amount. The difference in the mineralogical composition within the soils of semi-arid region was found to be originated from the source of the alluvium and parent rocks from which the soils are found.

\section{REFERENCES}

1. S. Dutta and A.V. Shanwal, Potassium Depletion and Illite Transformation with Time in Typic Haplustept Under Long Term Experiment at Hisar, India, Proc. Intl. Symp. On Importance of Potassium in Nutrient Management Sustainable Crop Production in India. Potash Research Institute of India, Gurgaon, Haryana, India, vol. 1, pp. 39-42 (2001).

2. J.S. Chaudhary, P.S. Sindhu, R.P. Dhir and R.L. Ahuja, Chemical composition and mineralogy. Rev. Res. On Sandy Soil of India. International Symposium on Managing Sandy Soils. Central Arid Zone Research Institute, Jodhpur, India, pp. 65-84 (1989).

3. A.V. Shanwal and S. Dutta, Forms of Potassium and K Bearing Minerals in Soils of Some Agroclimatic Zones of India. International Symposium On importance of Potassium in Nutrients Management for Sustainable Crop Production in India (Dec. 3-5, 2001), New Delhi (2001).

4. S. Magnus, S. Hillier and I. Oborn, Geroderma, 151, 109 (2009).

5. O. Gjems, Studies on Clay Minerals and Clay Mineral Formation in Soils Profiles in Scandinavian Meddelser form Det Norske Skogforsok Svesen No. 81 Bind 21, Vollbeekh, Norway (1967).

6. S.K. Ghosh and N.P. Dutta, Proc. Indian Natl. Sci. Acad., 40, 138 (1974).

7. A.V. Shanwal and S. Dutta, Contribution of Different Particle Size Fractions of Varied Mineralogy Soils Towards Potassium Availability Under Intensive Cropping. International Symposium On Importance of Potassium in Nutrients Management for Sustainable Crop Production in India (Dec. 3-5, 2001), New Delhi (2001).

8. R. Kumar, P. S. Sindhu, B.D. Sharma and R. Kumar, Agropedology, 10, 240 (2000).

9. D.C. Nakyak and D. Sarkar, Clay Res., 24, 255 (2005).

10. A.K. Raina, S.D. Sharma and M.N. Jha, J. Indian Soc. Soil Sci., 54, 638 (2006) 